\title{
Cultivation-Dependant Assessment, Diversity, and Ecology of Haloalkaliphilic Bacteria in Arid Saline Systems of Southern Tunisia
}

\author{
Darine El Hidri, ${ }^{1,2}$ Amel Guesmi, ${ }^{1}$ Afef Najjari, ${ }^{2}$ Hanen Cherif, ${ }^{1}$ Besma Ettoumi, \\ Chadlia Hamdi, ${ }^{1}$ Abdellatif Boudabous, ${ }^{1}$ and Ameur Cherif ${ }^{1,2}$ \\ ${ }^{1}$ Laboratory of Microorganisms and Active Biomolecules, Faculty of Sciences of Tunis, University of Tunis El Manar, \\ 2092 Tunis, Tunisia \\ ${ }^{2}$ LR Biotechnology and Bio-Geo Resources Valorization, Higher Institute for Biotechnology, Biotechpole Sidi Thabet, \\ University of Manouba, 2020 Ariana, Tunisia
}

Correspondence should be addressed to Ameur Cherif; cherif.ameur@gmail.com

Received 30 April 2013; Revised 31 August 2013; Accepted 14 September 2013

Academic Editor: George Tsiamis

Copyright (C) 2013 Darine El Hidri et al. This is an open access article distributed under the Creative Commons Attribution License, which permits unrestricted use, distribution, and reproduction in any medium, provided the original work is properly cited.

\begin{abstract}
Haloalkaliphiles are polyextremophiles adapted to grow at high salt concentrations and alkaline $\mathrm{pH}$ values. In this work, we isolated 122 haloalkaliphilic bacteria upon enrichments of 23 samples from 5 distinct saline systems of southern Tunisia, growing optimally in media with $10 \%$ salt and at $\mathrm{pH} 10$. The collection was classified into 44 groups based on the amplification of the 16S-23S rRNA internal transcribed spacers (ITS-PCR). Phylogenetic analysis and sequencing of the 16S rRNA genes allowed the identification of 13 genera and 20 distinct species. Three gram-positive isolates showing between 95 and 96\% of $16 \mathrm{~S}$ rRNA sequence homology with Bacillus saliphilus could represent new species or genus. Beside the difference in bacterial diversity between the studied sites, several species ecological niches correlations were demonstrated such as Oceanobacillus in salt crust, Nesterenkonia in sand, and Salinicoccus in the rhizosphere of the desert plant Salicornia. The collection was further evaluated for the production of extracellular enzymes. Activity tests showed that gram-positive bacteria were mostly active, particularly for protease, lipase, DNase, and amylase production. Our overall results demonstrate the huge phenotypic and phylogenetic diversity of haloalkaliphiles in saline systems of southern Tunisia which represent a valuable source of new lineages and metabolites.
\end{abstract}

\section{Introduction}

Extreme environments are distributed on Earth which were thought to prevent the existence of life. These habitats are characterized by extreme conditions including physical (temperature and pressure) and chemical parameters (salinity and pH) [1]. Major categories of extremophiles include halophiles, thermophiles, acidophiles, alkaliphiles, and haloalkaliphiles. The microflora of high salinity ecosystems has attracted a great deal of attention from researchers in this last decade, especially haloalkaliphiles bacteria. In 1982, the term haloalkaliphile was used for the first time to describe bacteria that are both halophilic and alkaliphilic [2]. This group of bacteria is able to grow optimally or very well at $\mathrm{pH}$ values at or above 10 along with high salinity (up to $25 \%(w / v) \mathrm{NaCl}$ ) [3].
To adapt in such conditions, haloalkaliphilic microorganisms have developed various physiological strategies to maintain their cell structure and function $[4,5]$. These bacteria have largely been identified and studied from the hypersaline environments, soda lakes, solar saltern, salt brines, carbonate springs, and Dead Sea [6]. Their existence clearly indicated the widespread distribution of such organisms in natural saline environments $[4,7]$.

During the past years special attention has been focused on the distribution of haloalkaliphilic bacteria diversity in different hypersaline and hyperalkaline environments [8]. Culture based methods are usually used to investigate biochemical and genetic diversity by selecting a particular population of microorganisms [9]. Molecular microbial surveys 
based on 16S rRNA gene have been adopted to study the phylogenetic diversity in different extreme environments [1014]. Generally, saline systems are dominated by representatives of the domain Bacteria [15-21]. They possess special adaptation mechanisms to survive, grow, and thrive under high salinity and alkaline $\mathrm{pH}$. This dual extremity of halophile and alkaliphile makes these microorganisms very interesting from the fundamental and biotechnological research sides [22].

The interest in haloalkaliphilic microorganisms is due not only to the necessity for understanding the mechanisms of adaptation to multiple stresses and detecting their diversity, but also to their possible application in biotechnology. Research efforts focused on the discovery of industrial enzymes capable of performing their function under harsh conditions have greatly increased over the past decade [7, 22, 23]. These enzymes include proteases, lipases, amylases, and DNase, viewed as important candidates for various industries such as food, detergent, chemical, pharmaceutical, paper, and pulp or waste treatment [4]. Southern Tunisia features numerous ecosystems including coastal and inland salt lakes, respectively, named Sabkha or Sabkhet, and Chotts [24]. These environments are characterized by unstable climatic conditions, due to the periodic flooding by the subsurface ground water associated with high salt conditions during dry phases, making them fascinating ecosystems to study the diversity and the ecological adaptations of microorganisms thriving in saline systems.

To our knowledge, no studies have been carried out in order to describe the diversity of haloalkaliphilic bacteria from North African arid and hypersaline systems. The present work aimed to evaluate the diversity of haloalkaliphilic strains isolated from the inland Chotts and the coastal Sebkha hypersaline systems in Tunisian Sahara, based on different phylogenetic markers and biochemical patterns.

\section{Materials and Methods}

2.1. Sample Collections. All enrichments and strains described here were isolated from twenty-three samples collected from arid saline systems in southern Tunisia during February 2008 and 2010: salt crust, hypersaline water, thermomineral water, sand, sediment (with or without salt), bulk soil, algal biofilm, and the rhizosphere of the desert plant Salicornia when present. The sampling sites include three continental ephemeral salt lakes: Chott el Djerid (9 samples from 4 sites: BDV17, N $33^{\circ} 59^{\prime} 558^{\prime \prime}$, E $08^{\circ} 39^{\prime} 212^{\prime \prime}$; BDV18, N $33^{\circ} 58^{\prime} 736^{\prime \prime}$, E $08^{\circ} 20^{\prime} 632^{\prime \prime}$; BDV19, N $33^{\circ} 57^{\prime} 252^{\prime \prime}$, E $08^{\circ} 24^{\prime} 507^{\prime \prime}$; BDV20, N $33^{\circ} 57^{\prime} 252^{\prime \prime}$, E $08^{\circ} 24^{\prime} 508^{\prime \prime}$ ), Chott el Douz (3 samples from site BDV6: N 33 $28^{\prime} 204^{\prime \prime}$, E $08^{\circ} 56^{\prime} 733^{\prime \prime}$ ), and Sabkhet Ennaouel (2 samples from BDV4: $\left.\mathrm{N} 34^{\circ} 26^{\prime} 951^{\prime \prime}, \mathrm{E} 09^{\circ} 54^{\prime} 102^{\prime \prime}\right)$; one coastal salt lake, Sabkhet El Melah (4 samples from BDIII-11: N $33^{\circ} 25^{\prime} 119^{\prime \prime}$, E $11^{\circ} 00^{\prime} 523^{\prime \prime}$ ), and one nonsaline system; Ksar Ghilane Oasis (5 samples from 2 sites: $\mathrm{BDV} 1, \mathrm{~N} 32^{\circ} 59^{\prime} 012^{\prime \prime}$, E $09^{\circ} 38^{\prime} 072^{\prime \prime}$; BDV2, N $32^{\circ} 59^{\prime} 293^{\prime \prime}$, E $09^{\circ} 38^{\prime} 374^{\prime \prime}$ ) (Figure 1). Samples were collected into sterile flasks and kept aseptically at $4^{\circ} \mathrm{C}$ until analyzed.
2.2. Enrichment and Isolation of Haloalkaliphilic Bacteria. Enrichment was performed on Soap lake Basal Medium (SLBM) [25], an enrichment medium for moderately haloalkaliphilic bacteria, containing $\left(\mathrm{L}^{-1}\right): \mathrm{CaSO}_{4} 4 \mathrm{mg} ; \mathrm{FeSO}_{4}$ $1 \mathrm{mg} ; \mathrm{NaCl} 10 \mathrm{~g} ; \mathrm{SiO}_{2} 5 \mathrm{mg} ; \mathrm{MgCl}_{2} 4 \mathrm{mg} ; \mathrm{MnSO}_{4} 4 \mathrm{mg}$; $\mathrm{NH}_{4} \mathrm{O}_{3} 50 \mathrm{mg} ; \mathrm{Na}_{2} \mathrm{SO}_{4} 13 \mathrm{~g} ; \mathrm{KH}_{2} \mathrm{PO}_{4} 3 \mathrm{~g} ; \mathrm{K}_{2} \mathrm{HPO}_{4} 3 \mathrm{~g}$; $\mathrm{Na}_{2} \mathrm{CO}_{3} 1 \mathrm{~g}$, and $1 \mathrm{~mL}$ trace element stock solution consisting of $\left(\mathrm{L}^{-1}\right)$ sodium nitriloacetate $1.5 \mathrm{~g} ; \mathrm{MgSO}_{4} \cdot 7 \mathrm{H}_{2} \mathrm{O} 3 \mathrm{~g}$; $\mathrm{MnSO}_{4} \cdot 7 \mathrm{H}_{2} \mathrm{O} 0.5 \mathrm{~g} ; \mathrm{NaCl} 1 \mathrm{~g} ; \mathrm{FeSO}_{4} \cdot 7 \mathrm{H}_{2} \mathrm{O} 0.1 \mathrm{~g} ; \mathrm{CaCl}_{2} \cdot 2 \mathrm{H}_{2} \mathrm{O}$ $0.1 \mathrm{~g} ; \mathrm{CoCl}_{2} \cdot 6 \mathrm{H}_{2} \mathrm{O} 0.1 \mathrm{~g} ; \mathrm{ZnCl}_{2} 0.13 \mathrm{~g} ; \mathrm{CuSO}_{4} \cdot 5 \mathrm{H}_{2} \mathrm{O} 0.01 \mathrm{~g}$; AlK $\left(\mathrm{SO}_{4}\right)_{2} \cdot 12 \mathrm{H}_{2} \mathrm{O} 0.01 \mathrm{~g} ; \mathrm{H}_{3} \mathrm{BO}_{3} 0.01 \mathrm{~g} ; \mathrm{Na}_{2} \mathrm{MoO}_{4} \cdot 2 \mathrm{H}_{2} \mathrm{O}$ $0.025 \mathrm{~g} ; \mathrm{NiCl}_{2} \cdot 6 \mathrm{H}_{2} \mathrm{O} 0.024 \mathrm{~g}$, and $\mathrm{Na}_{2} \mathrm{WO}_{4} \cdot 2 \mathrm{H}_{2} \mathrm{O} 0.025 \mathrm{~g}$. The final $\mathrm{pH}$ of the medium was adjusted to 10 by adding $5 \mathrm{M}$ $\mathrm{NaOH}$ before autoclaving. One $\mathrm{g}$ or $1 \mathrm{~mL}$ of each sample was added to $20 \mathrm{~mL}$ of SLBM and incubated in a shaking incubator $(200 \mathrm{rpm})$ at $30^{\circ} \mathrm{C}$ for 5 days. Serial dilutions of the enriched cells were plated on solid SLBM [25]. Plates were incubated at $30^{\circ} \mathrm{C}$ for 5 days. Colonies growing on the plates were selected based on morphological features, considering pigmentation and size. Each isolate was subjected to successive streak plating until a pure colony was obtained. The isolates were stored in glycerol stocks $(25 \% \mathrm{v} / \mathrm{v})$ at $-80^{\circ} \mathrm{C}$.

2.3. DNA Extraction and PCR Conditions. Genomic DNA of bacteria was extracted by sodium dodecyl sulfate-proteinase $\mathrm{K}$ treatment [26]. The $16 \mathrm{~S}$ rRNA gene from pure cultures was amplified as a $1.5 \mathrm{~kb}$ DNA fragment by PCR using the universal primers S-D-Bact-0008-a-S-20 (5' -CTA CGG CTA CCT TGT TAC GA-3 $\left.{ }^{\prime}\right)$ and S-D-Bact-1495-a-S-20 (5'-AGA GTT TGA TCC TGG CTC AG-3') [26]. 16S-23S rRNA ITS were amplified using the universal primers S-D-Bact-1494a-20 (5'-GTC GTA ACA AGG TAG CCG TA- $\left.3^{\prime}\right)$ and LD-Bact-0035-a-15 (5'-CAA GGC ATC CAC CGT-3') [27]. PCR amplification was carried out according to the procedure described previously [26]. The presence of specific PCR products was verified by electrophoresis on $1.5 \%$ and $2 \%(\mathrm{w} / \mathrm{v})$ agarose gels for 16S rRNA and ITS amplicons, respectively.

2.4. Sequencing and Phylogenetic Analysis of $16 S$ rRNA Sequences. The $16 \mathrm{~S}$ rRNA gene sequencing has been carried with an automated capillary ABI Biosystem 3130. The obtained sequences were identified by comparison with those available at the National Centre for Biotechnology Information (NCBI) database (http://www.ncbi.nlm.nih.gov) using the BLAST program [28]. The sequences were aligned using Clustal W version 1.8 [29]. Evolutionary distances were computed using Jukes and Cantor method [30]. Phylogenetic dendrograms were constructed by the neighbor-joining method and trees topology was evaluated by performing bootstrap analysis of 1000 data sets using MEGA 4.1 (Molecular Evolutionary Genetics Analysis) [31]. The sequences reported in this study have been submitted to NCBI GenBank and the accession numbers are listed in Table 1.

2.5. Morphological and Physiological Characterization of Isolates. Gram staining of all isolates was performed according to the method of Murray and colleagues [32]. Growth of strains at different $\mathrm{pH}$ values was determined in solid SLBM, 


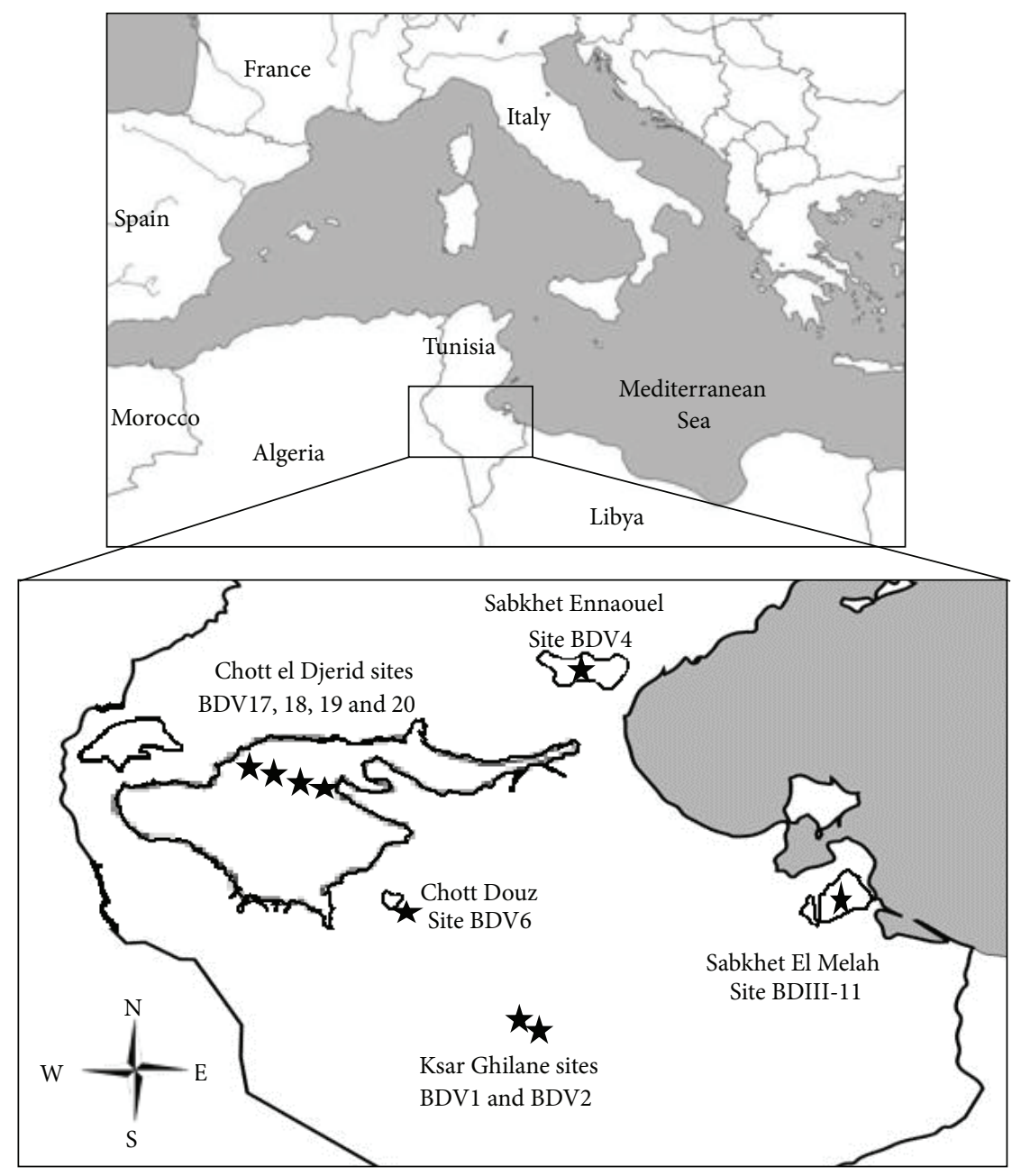

Figure 1: Location of the sampled sites: BDV1 and BDV2 (Oasis Ksar Ghilane), BDV4 (Sabkhet Ennaouel), BDV6 (Chott el Douz), BDV17, BDV18, BDV19, BDV20 (Chott el Djerid), and BDIII-11 (Sabkhet El Melah).

in which the $\mathrm{pH}$ was adjusted to $7.0,10$, and 11 . The ability of strains to grow at different range of salinity at $\mathrm{pH} 10$ and $\mathrm{pH} 7$ was performed in solid SLBM plates supplemented with $0,5,10,15,20$, and $25 \% \mathrm{NaCl}(\mathrm{w} / \mathrm{v})$. Growth behaviors were observed after 5 days of incubation at $30^{\circ} \mathrm{C}$.

2.6. Screening of Strains for Extracellular Hydrolytic Activities. A qualitative screening was performed to detect the ability of the isolated bacteria to produce extracellular enzymes responsible for hydrolytic activities. The tests were performed on different solid media containing $10 \% \mathrm{NaCl}$ at $\mathrm{pH} 10$. For alkaline protease detection, SLBM agar medium supplemented with $1 \%(\mathrm{w} / \mathrm{v})$ skim milk was used as described previously $[4,33]$. A clear zone around the colony after 5 days of incubation was taken as evidence of proteolytic activity. Amylase activity was performed according to the method described by Amoozegar and colleagues [34]. The presence of amylolytic activity on plates was determined qualitatively using SLBM agar medium supplemented with $0.5 \%(\mathrm{w} / \mathrm{v})$ soluble starch. After incubation at $30^{\circ} \mathrm{C}$ for 5 days, the plates were flooded with $0.3 \% \mathrm{I}_{2}-0.6 \% \mathrm{KI}$ solution. A clear zone around the growth indicated the hydrolysis of starch [35]. DNase activity of the strains was determined using DNase test agar medium. After incubation at $30^{\circ} \mathrm{C}$ for 5 days, the plates were flooded with toluidine blue $(0.1 \%)(\mathrm{w} / \mathrm{v})$. A pink halo around the colonies showed the secretion of DNase [36]. Lipase screening was achieved based on the method of Gutiérrez and González [37] using Tween 20 as a substrate. The presence of lipase activity was demonstrated by the formation of white halo due to the formation of precipitates of calcium laurate around the growth after 5 days of incubation at $30^{\circ} \mathrm{C}$

\section{Results and Discussion}

3.1. Isolation and Characterization of Haloalkaliphilic Bacteria. The diversity of cultivable haloalkaliphilic bacteria was evaluated using culture enrichment followed by isolation on haloalkaliphile medium. A total of 23 samples collected from 4 distinct saline stations (Sabkhas and Chotts) and one desert station were processed. The morphological characteristics of the isolates showed a wide variability including size, color, 


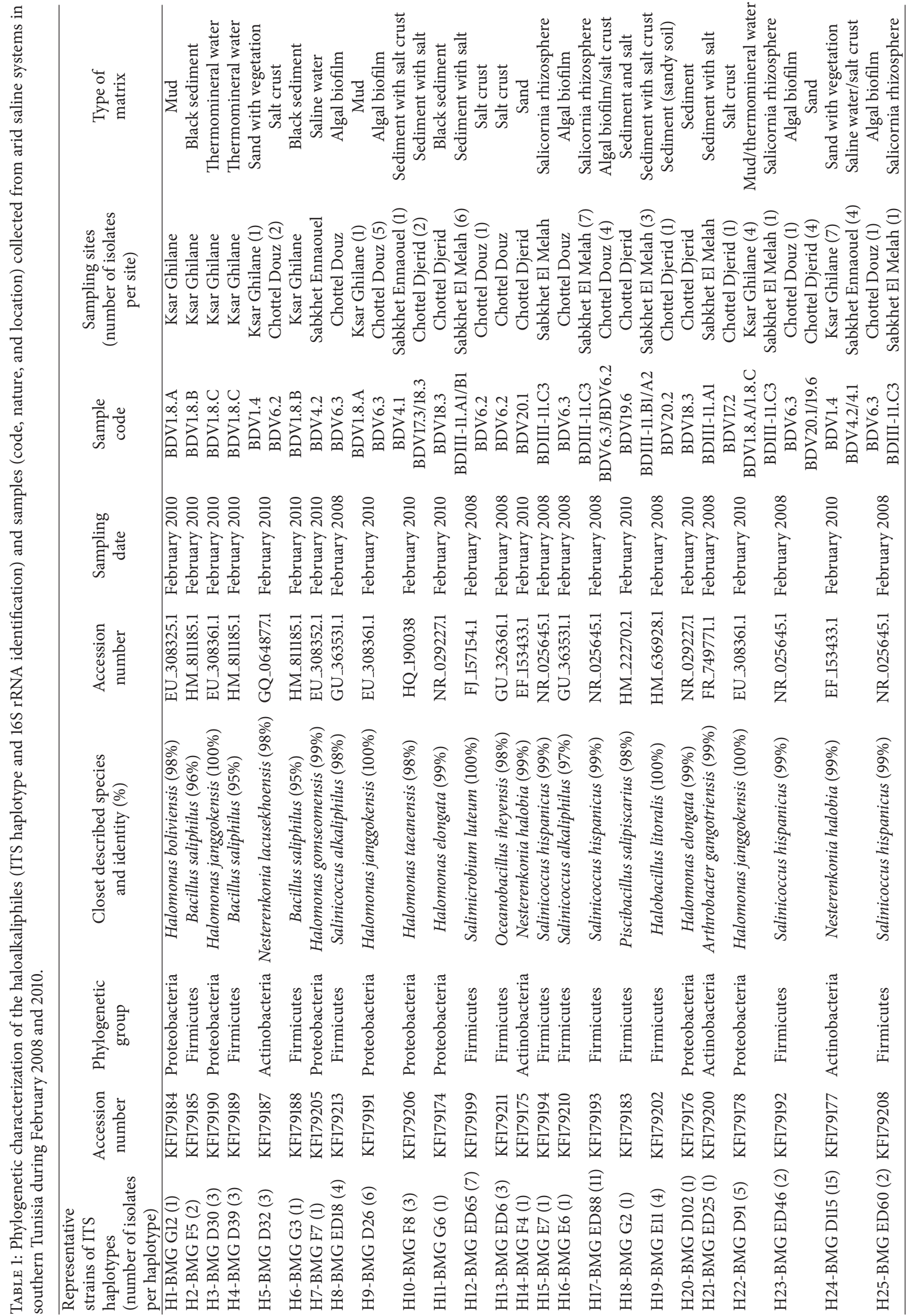




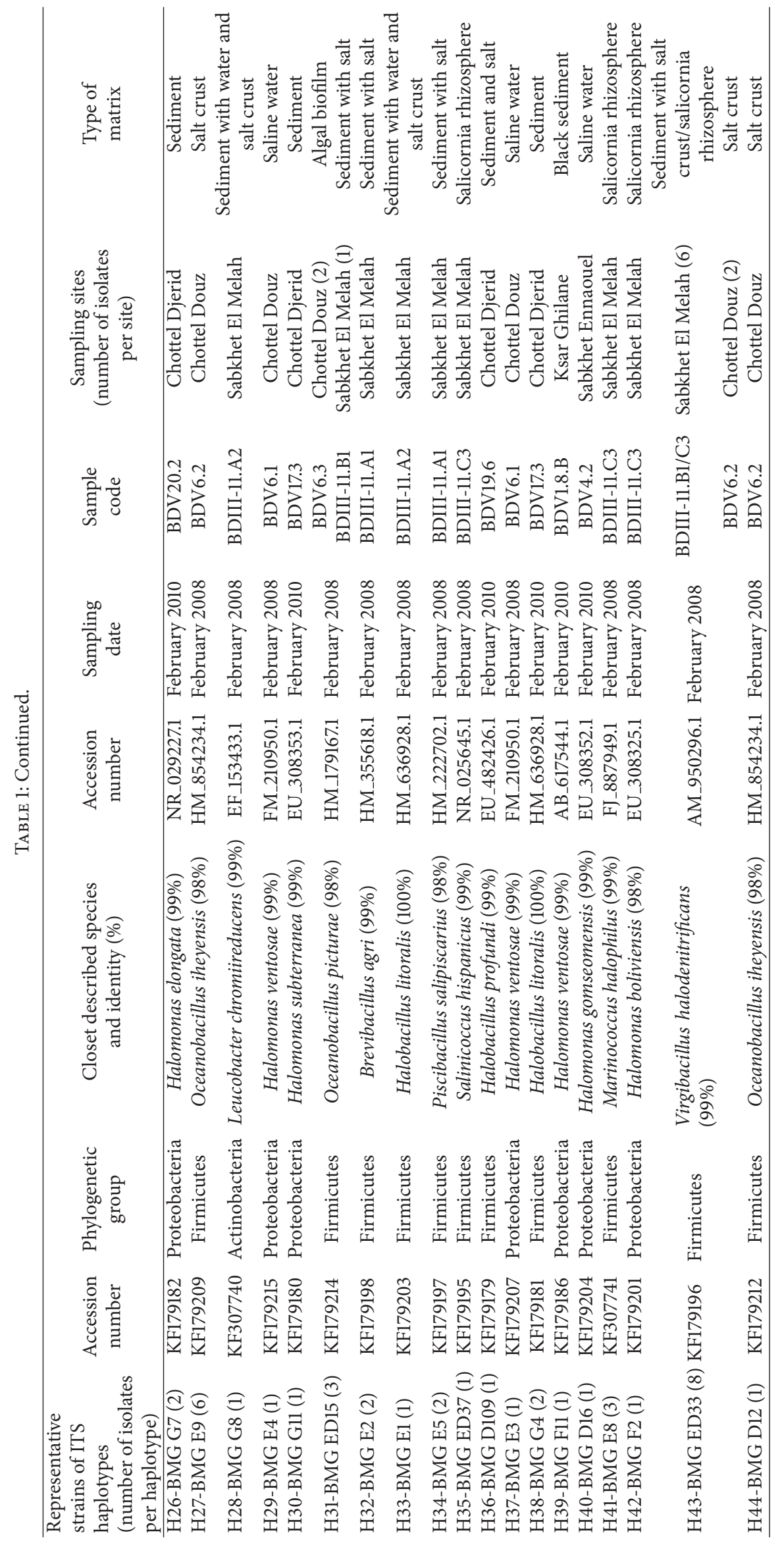


and margin, with $76.15 \%$ of them being Gram-positive. The versatility to grow in different range of $\mathrm{NaCl}$ concentrations and $\mathrm{pH}$ values is reported in Table 2. On the basis of their salt tolerance, the collection could be classified into three groups: extremely halotolerant (growing at $\mathrm{NaCl}$ concentration ranging from 0 to 25\%), moderate halotolerant (growing between 0 and $10 \% \mathrm{NaCl}$ ), and strict halophilic bacteria (i.e., that cannot be cultured without salt). Similarly, depending on their tolerance to $\mathrm{pH}$, strains can be divided into two groups: facultative alkaliphile which represent the dominant fraction of the collection $(81.15 \%)$ and obligate alkaliphile bacteria (18.85\%).

Extremely halotolerant bacteria, in which their salt tolerance ranged between 0 and 15,20 , or $25 \%(\mathrm{w} / \mathrm{v})$ represented the major part of this collection (71.3\%). In similar studies, strains isolated from alkaline Lonar lake in India [7] and from mineral pool in Campania (southern Italy) [38] were shown to be extremely haloalkalitolerant, tolerating high concentrations of $\mathrm{NaCl}$ up to $25 \%$ and different $\mathrm{pH}$ values (710).

Combining the salt and $\mathrm{pH}$ requirements and their effects on the growth, the group of bacteria that could be considered as obligate haloalkaliphiles represent $24.5 \%(n=30)$ of the collection. They were mainly isolated from the extreme saline systems of Chott el Djerid, Sabkhet El Melah, and Chott el Douz (Tables 1 and 2). The ability of haloalkaliphilic strains to grow at a wide range of salinities and $\mathrm{pH}$ could be assigned to their adaptation to the changing levels of salinity and by evolving typical strategies to cope with salt stress: osmoregulation and modification in cell morphology and structure $[39,40]$. It is interesting to note that a subcollection (23 isolates) of the obligate haloalkaliphiles showed variability in their salt tolerance with different $\mathrm{pH}$ values. At alkaline $\mathrm{pH}$ (10-11), they were able to cope with the absence of salt, but at neutral $\mathrm{pH} 7$, they require an amount of $\mathrm{NaCl}$ higher than $1 \%$. They were thus considered as strict halophilic bacteria at neutral pH. Only 7 isolates (5.73\%) from Sabkhet El Melah and Chott el Douz were shown to be strict halophiles at all $\mathrm{pH}$ values (Tables 1 and 2). The exact relation between the salt requirement and tolerance and the $\mathrm{pH}$ homeostasis in the cell, raises several questions and represents an interesting issue to be studied [7]. Studies on aerobic alkaliphilic bacteria thriving in alkaline Lonar Lake in India showed that obligate haloalkaliphles related to the genus Alkalibacillus could be isolated only in specific medium containing $2 \% \mathrm{NaCl}$ and at pH 10 [7].

A fraction of $4.1 \%$ of our collection was classified as moderate haloalkaliphiles $(0-10 \%$ of $\mathrm{NaCl}$ growth range), a proportion similarly isolated from other different saline and alkaline environments [41-47]. Occurrence of haloalkalitolerant, obligate, and moderate haloalkaliphiles bacteria, in different sampling locations, highlighted the diversity and the widespread distribution of these microorganisms in arid-saline systems of southern Tunisia. This versatility of growth characteristics could be explained by their ability of osmoregulation, in relation with alkaline $\mathrm{pH}$, through which they maintain an internal osmotic potential that equals their external environment [48].
3.2. Bacterial Collection Dereplication and Identification. ITS fingerprinting method is a molecular tool based on the sequence and length heterogeneity of the bacterial rRNA operon 16S-23S intergenic spacer and provides a high phylogenetic resolution. It can discriminate bacterial isolates up to the subspecies level $[26,49,50]$. To manage the large set of isolates in our collection, ITS-PCR fingerprinting was applied as a first screening method. Among the 122 isolates, 44 distinct haplotypes ( $\mathrm{H} 1-\mathrm{H} 44)$ were detected. All profiles were composed by 1 up to 8 reproducible bands of approximate sizes ranging from 180 to $800 \mathrm{bp}$ (Figure 2).

The most encountered haplotype was ITS-H24 revealed in 15 strains isolated from sand and sediment samples collected from Ksar Ghilane, Chott el Djerid, and Sabkhet Ennaouel. Strains belonging to this haplotype were classified as strict halophile (at $\mathrm{pH}$ 7) and extremely halotolerant at alkaline $\mathrm{pH}$ ( $\mathrm{pH} 10-11)$. The second most frequent represented pattern was haplotype ITS-H17 present in 11 strains isolated from Salicornia plants rhizosphere and algal biofilm collected from Sabkhet El Melah and Chott el Douz, respectively. These strains were found to be able to grow in media with $15 \%$ $\mathrm{NaCl}$ and $\mathrm{pH}$ ranging from 7 to 11 . Other ITS haplotypes were frequently encountered like ITS-H43 in 8 isolates and ITS-H9, and H12 shown by 6 strains. The remaining ITS haplotypes were shown to be, in the major part, strains specific haplotypes (Table 1).

Partial 16S rRNA gene sequencing was performed for representative isolates of each distinct haplotype $(n=44)$ and analyzed using BLAST. Phylogenetic analysis revealed that the isolates were allocated into thirteen different genera with an uneven distribution: Halomonas, Salinicoccus, Nesterenkonia, Oceanobacillus, Virgibacillus, Halobacillus, Salimicrobium, Bacillus, Piscibacillus, Marinococcus, Brevibacillus, Leucobacter, and Arthrobacter. They were placed into the three major bacteria phyla Firmicutes, Actinobacteria and Gammaproteobacteria. In a similar work, microbial diversity analysis in water and sediment of lake Chaka, a hypersaline lake on Tibetan plateau, permitted the assignation of bacterial community into the same three groups of Firmicutes, Gammaproteobacteria, and Actinobacteria [51].

The Firmicutes phyla including Bacillus, Halobacillus, Piscibacillus, Oceanobacillus, Virgibacillus, Salimicrobium, Marinococcus and Salinicoccus were more abundant and diverse. They constitute also the obligate haloalkaliphiles fraction at neutral $\mathrm{pH}$ (Halobacillus, Piscibacillus, and Marinococcus) and at all $\mathrm{pH}$ values (Salimicrobium that needs at least $5 \% \mathrm{NaCl}$ to grow) (Table 2). Compared to similar studies carried out on salt lake [21, 44, 52], marine habitat $[20,53]$, and other hypersaline sediments [47] where limited number of genera were identified, arid saline systems of Tunisia revealed a highly diverse community. The isolates obtained from Alkaline Lonar lake in India were associated with the members of diverse Bacillus related genera (Paenibacillus, Bacillus, and Alkalibacillus) [7]. While in deepsea hypersaline lakes, taxonomic analyses showed that twothirds of 89 isolates were mostly representative of the genus Bacillus and the related genera Halobacillus, Virgibacillus, and Pontibacillus [54]. In comparison to these reports, Bacillus 


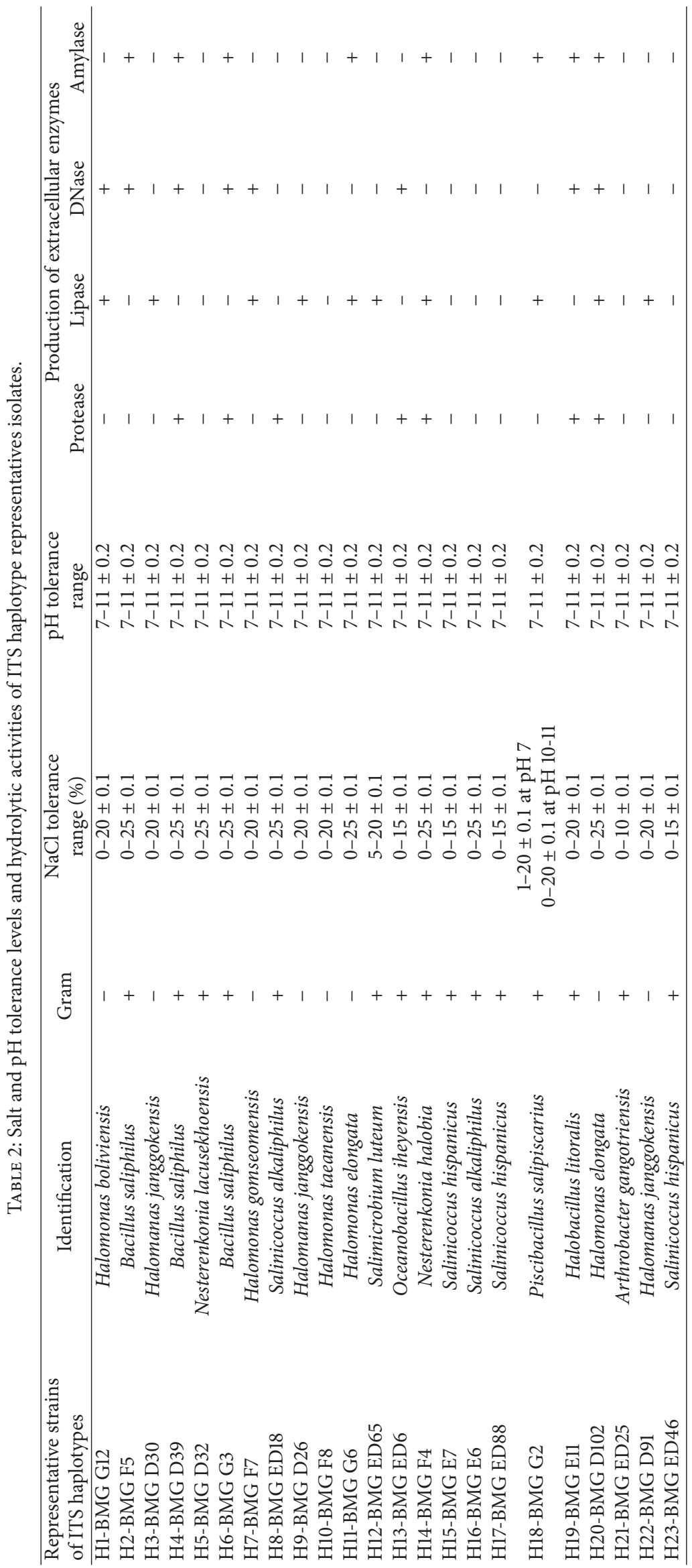




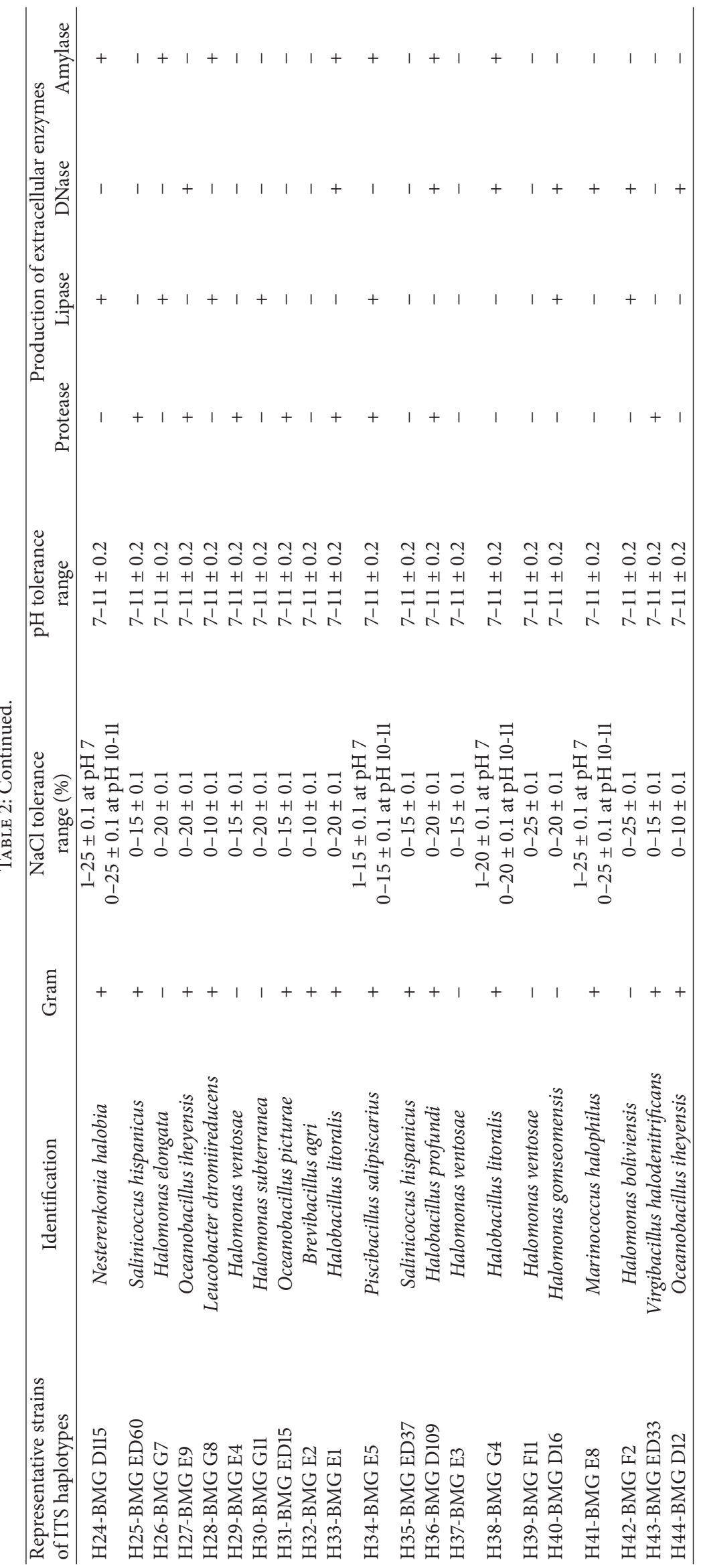




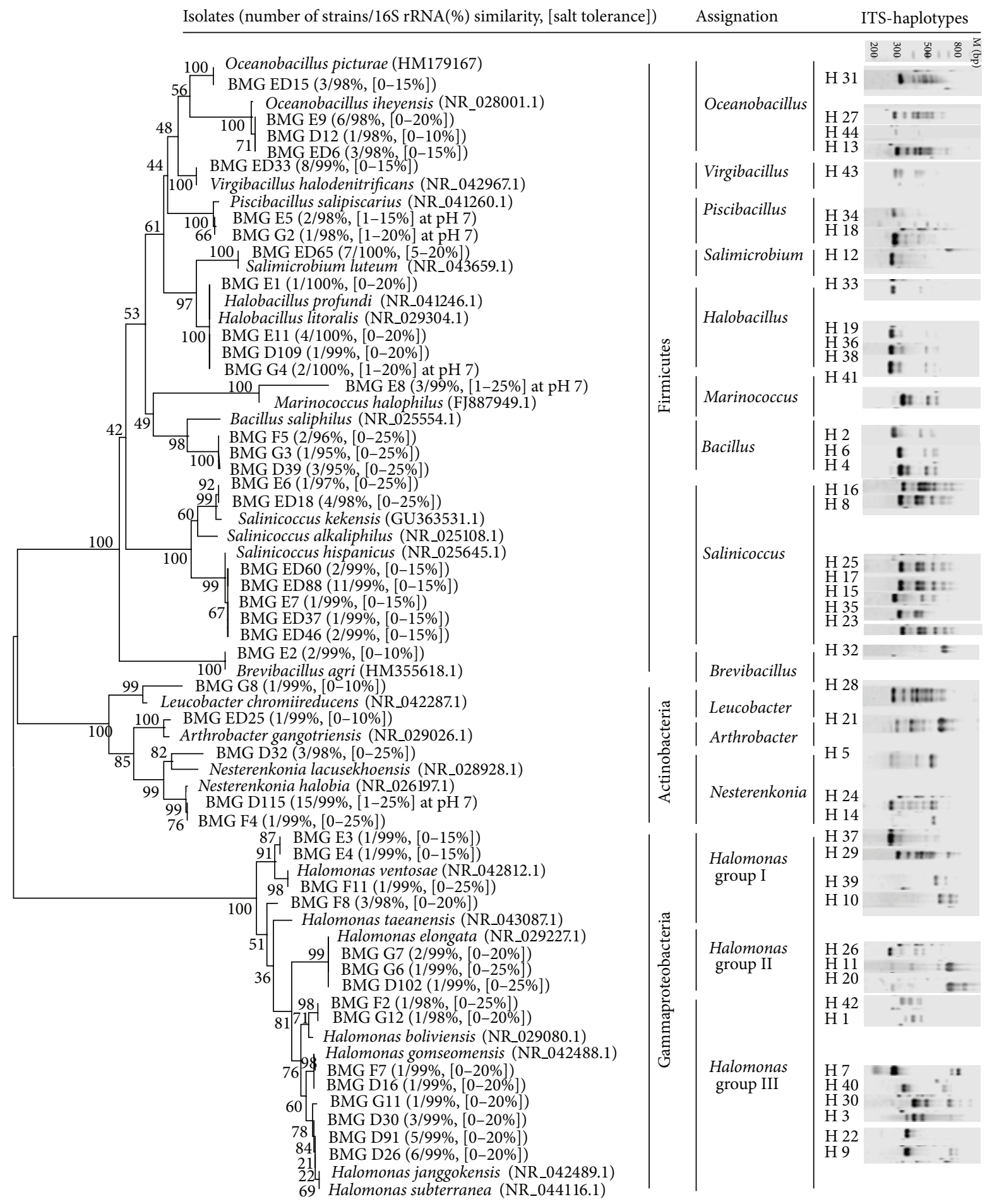

FIGURE 2: Phylogenetic diversity of haloalkaliphilic bacteria. (a) Unrooted phylogenetic tree of 44 partial $16 \mathrm{~S}$ rRNA sequences (500 bp) of the arid saline system isolates with the 24 closest phylogenetic relatives. The method of Jukes and Cantor was used to calculate evolutionary distances and tree topology was constructed using MEGA 4.0. Bootstrap values ( $n=1000$ replicates) were indicated at the nodes. The number of isolates per ITS haplotype, the $16 \mathrm{~S}$ rRNA similarity percentage (refseq rna database), and $\mathrm{NaCl}$ range for growth at $\mathrm{pH} 11$ (or at $\mathrm{pH} 7 \mathrm{where}$ mentioned), are indicated in parenthesis. (b) 16S-23S rRNA ITS haplotypes of 44 representative isolates as resolved on $2 \%$ agarose gels. ITS haplotype numbers are indicated. Lane $\mathrm{M}$ corresponds to a $100 \mathrm{bp}$ ladder. 
species are among the most commonly found aerobic, bacterial alkaliphiles, both in Soda lakes and in less selective environments [44, 55-58]. The same result was observed in other arid saline systems such as the Golea Salt lake in Algeria Sahara [52], Chott el Djerid [21, 44, 59] and Tunisian multipond solar saltern $[18,58,59]$. This high occurrence and the ability of Bacillus and Bacillus related genera to tolerate salt and alkaline stress prove that they are well adapted to arid-saline environments being physiologically active and not only present as dormant spores. Indeed, recent report indicated that they contribute to the system biological robustness and function [60]. Three Bacillaceae strains (BMG F5, BMG D39, and BMG G3) isolated from sediments and thermomineral water from Ksar Ghilane BDV1.8 site (a thermomineral natural pool) showed a very low $16 \mathrm{~S}$ rRNA sequence homology (95-96\%) with Bacillus saliphilus that was previously isolated from mineral pool in southern Italy [38]. The Ksar Ghilane strains could represent new alkaliphilic and extremely halotolerant species related to B. saliphilus, particularly adapted to high mineral concentrations in desert environment.

Other species-microniche correlations are noteworthy. Oceanobacillus iheyensis strains $(n=10)$ were all isolated from salt crust samples, whereas Halobacillus $(n=8)$, Piscibacillus $(n=3)$, and Salimicrobium $(n=7)$ isolates were recovered from salty sediments and soils (Table 1). On the other hand, the 17 isolates identified as Salinicoccus hispanicus, 5 isolates of Salinicoccus alkaliphilus, and 3 isolates of Marinococcus halophilus were clearly associated with the rhizosphere of the desert plant Salicornia and algal biofilm. Whilst Marinococcus halophilus was recently described as a plant-growth promoting rhizospheric bacterium isolated from the same environment [21], this work constitutes the first report on the capabilities of haloalkaliphilic Salinicoccus species to colonize and thrive into the plant rhizosphere in desert environment.

The phylum Actinobacteria was represented by 4 species that belong to the Micrococcaceae family: Nesterenkonia halobia (16 isolates from Chott el Djerid, Sabkhet Ennaouel, and Ksar Ghilane; 99\% of 16S rRNA sequence identity), Nesterenkonia lacusekhoensis (3 isolates from Ksar Ghilane and Chott el Douz; 98\% of identity), Leucobacter chromiireducens (isolate BMG G8 from Sabkhet El Melah; 99\% of identity), and Arthrobacter gangotriensis (isolate BMG ED25 from Sabkhet El Melah; 99\% of identity). Species of the genus Nesterenkonia were previously reported as halotolerant and were isolated from different saline ecosystems like Brazilian Mangrove sediment [61] and hypersaline Ekho lake in East Antarctica [62]. Nesterenkonia halobia was also found as the unique Actinobacteria representative in Salicornia rhizosphere [21]. In the current prospection, N. lacusekhoensis and particularly $N$. halobia were recovered mainly from sand samples and showed changing halotolerance behavior at neutral and alkaline $\mathrm{pH}$ indicating a specific fine-tuned adaptation of these species to sand and salty sediments as ecological niche. With regard to the Arthrobacter species, they were previously reported as halotolerant and were isolated from east African soda lakes [63] and Antarctica
[64]. Interestingly, the moderate halophile isolates Leucobacter chromiireducens and Arthrobacter gangotriensis are not known to be natural inhabitant of arid-saline systems.

Gram-negative bacteria were represented by a unique genus Halomonas counting $23.87 \%$ of the whole collection, in accordance with the recent work of Mapelli et al. [21]. Halomonas isolates were retrieved from all sample types, assigned to 7 distinct species and clustered within 3 phylogenetic groups: (i) Halomonas group I including $H$. ventosae $(n=3)$, and $H$. taeanensis $(n=3)$; (ii) Halomonas group II represented by $H$. elongata $(n=4)$; and (iii) Halomonas group III constituted by $H$. boliviensis $(n=2), H$. gomseomensis $(n=2)$ and the related species $H$. janggokensis $(n=14)$ and $H$. subterranea $(n=1)$ (Table 1, Figure 2). Considering the nonmonophyletic status of the Halomonas genus and the need of a deep taxonomic revision [65], the number of recovered species indicates high intragenus diversity. In addition, there was no clear correlation between the recovered Halomonas species with their isolation origin, pointing out their adaptation capabilities to harsh conditions. Indeed, members of this genus have been isolated from diverse saline environments, including athalassohaline and thalassohaline Lakes and marine waters [20, 66]. However, by applying culture dependent and independent approaches $[18,20,58]$, more diverse communities including bacteria from the Alpha-, Beta-, Gamma-, and Deltaproteobacteria subclasses were revealed in similar ecosystems like the Inner Mongolian Soda Lake [17] and the hyperalkaline spring waters in Jordan [67]. The limited number of Gram-negative bacteria detected in our hypersaline samples may be due to the enrichment and culturing procedure that favor the growth of Gram-positive bacteria, as reported earlier [7], and where fast-growing alkalitolerant Halomonas sp. outcompete other Gram negative microorganisms at different $\mathrm{NaCl}$ concentration and $\mathrm{pH}$ values [51].

3.3. Geographic Distribution and Microdiversity. Arid environment and saline systems in southern Tunisia are characterized by unstable climatic conditions, due to the periodic flooding by the subsurface ground water associated with high salt during dry phases. These specific conditions make such environment fascinating ecosystems to study the diversity and the ecological adaptations of thriving microorganisms. In the current study, cultivation approach showed a particular distribution of haloalkaliphilic bacteria according to their sampling origin (Table 1, Figure 3). The general distribution of the genera was very similar in Ksar Ghilane, Sabkhet Ennaouel, and Chott el Djerid with low bacterial diversity and the dominance of Halomonas and Nesterenkonia species (Figure 3). Beside the specific occurrence of Nesterenkonia species in these stations, Bacillus saliphilus and Halobacillus profundi were exclusively isolated from Ksar Ghilane and Chott el Djerid, respectively.

Sabkhet El Melah showed the most diverse community displaying a mixture of strains affiliated into 11 genera. Among them, Arthrobacter, Leucobacter, Brevibacillus, and Marinococcus were exclusively detected in this site. In contrast, we noted the absence of Nesterenkonia strains, 

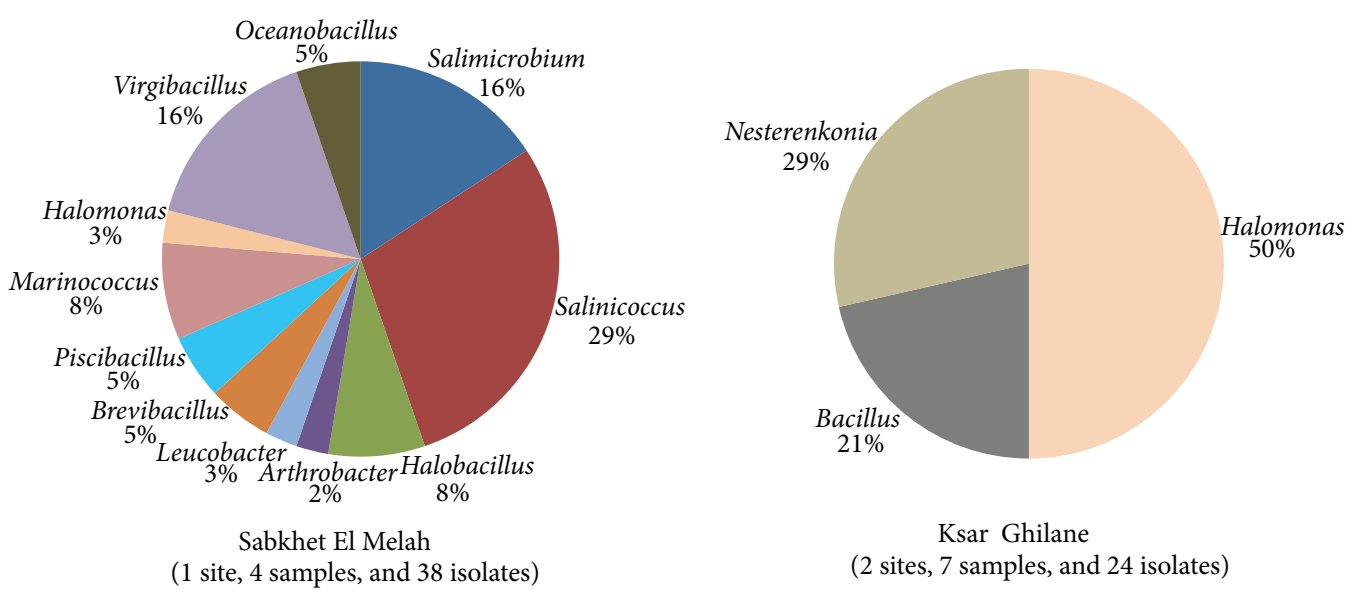

Ksar Ghilane

(2 sites, 7 samples, and 24 isolates)

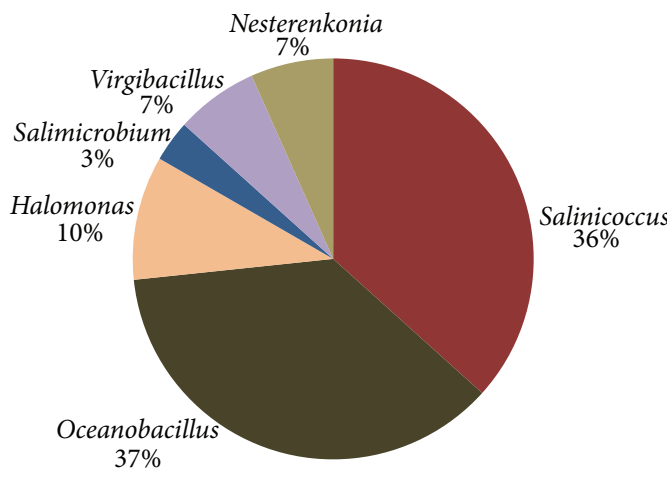

Chott Douz

(1 site, 3 samples, and 35 isolates)

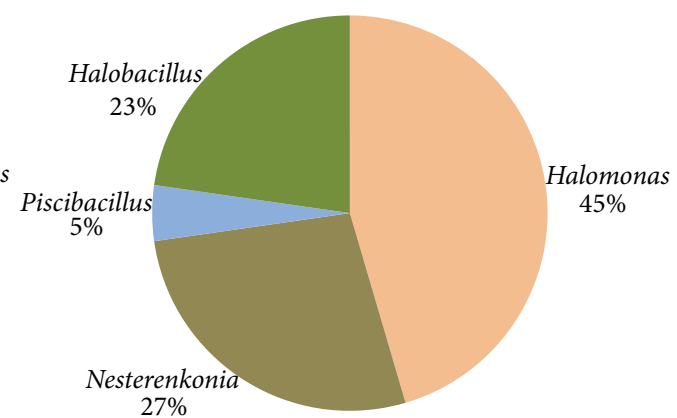

Chott Djerid

(4 sites, 9 samples, and 18 isolates)

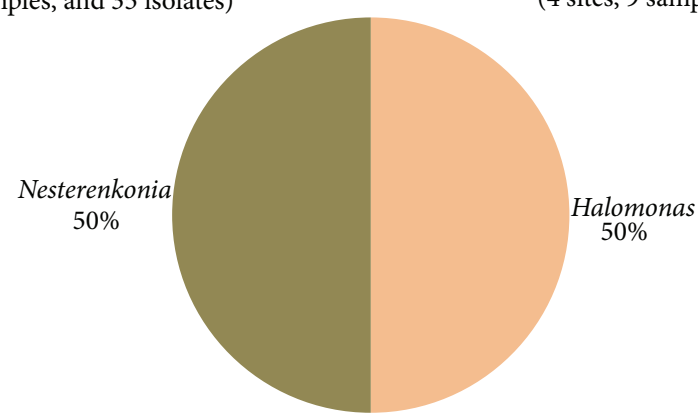

Sabkhet Ennaouel

(1 site, 2 samples, and 7 isolates)
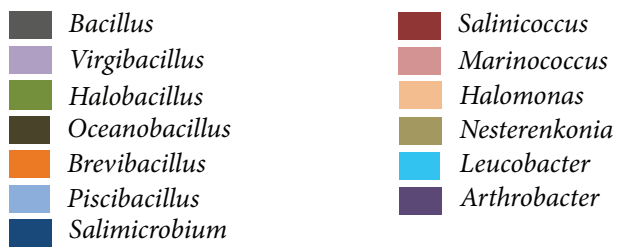

FIGURE 3: Geographic distribution of haloalkaliphilic bacteria isolated from natural saline systems of southern Tunisian Sahara.

frequently isolated from all the other sites (Figure 3). The high diversity detected in Sabkhet El Melah could be explained by its geographic location (a coastal saline system) that allows water exchange with the open sea. Indeed, the occurrence of Marinococcus halophilus (BMG E8 and two other isolates), a marine bacterium shown to be strict halophilic at neutral $\mathrm{pH}$, may indicate that the observed diversity is of marine origin rather than terrestrial. Besides, Leucobacter chromiireducens was first isolated from activated sludge of a waste water treatment plant contaminated with chromium and was shown to be halotolerant and able to tolerate up to $5 \mathrm{mM} \mathrm{Cr}(\mathrm{VI})$ [68]. Likewise, Arthrobacter gangotriensis is closely related to 
A. sulfurous isolated from oil contaminated sludge and able to achieve desulphurization [69]. The presence in Sabkhet El Melah of L. chromiireducens and A. gangotriensis related species may indicate anthropogenic and industrial pollution due to their vicinity to an offshore oil field and oil harbor terminal.

Chott el Douz is most similar to Sabkhet El Melah in terms of diversity with 6 distinct detected genera: Halomonas, Virgibacillus, Salimicrobium, and Nesterenkonia and a marked dominance of bacteria assigned to Oceanobacillus (37\%) and Salinicoccus (36\%). Interestingly, all the isolates assigned to Salinicoccus alkaliphilus ( $n=5$, ITS haplotypes H8 and H16) and to Oceanobacillus iheyensis ( $n=10$, ITS haplotypes $\mathrm{H} 13, \mathrm{H} 27$, and H44) occurred specifically in this site (Table 1, Figure 3). In similar studies, S. alkaliphilus was isolated from salt lakes; however, O. iheyensis is a deep-sea bacterium with original genomic futures and adaptive capabilities to changing environments $[5,70,71]$. The high prevalence of O. iheyensis species in salt crust samples of Chott el Douz confirms its adaptation potential to such extreme ecosystem.

The adaptive capabilities of the dominating haloalkaliphile species detected in the current study could be, in part, inferred to their intraspecific microdiversity. This microdiversity is highlighted by the number of ITS haplotypes displayed by a single or a complex of bacterial species. Salinicoccus hispanicus isolates, shown to thrive in plant rhizosphere and algal biofilm, were clustered in 5 ITS haplotypes (H15, H17, H23, H25, and H35). As well, Halomonas isolates recovered from all the sites were allocated into seven different species and 15 ITS haplotypes. Within this genus, Halomonas group III includes the 3 closely related species with 6 distinct ITS haplotypes: H. gomseomensis (H7 and $\mathrm{H} 40), H$. janggokensis ( $\mathrm{H} 2, \mathrm{H} 9$, and $\mathrm{H} 22$ ) and $H$. subterranea (H30). Isolates of these species that could be considered as a single one $[65,72]$ were recovered from all the sites except from Sabkhet El Melah (Table 1, Figure 3). Their high level of microdiversity could contribute to their ecological fitness and their ability to adapt to desert and saline environments. Overall, the microdiversity is attributed to different combinations of DNA sequence blocks making the genome more competent to accumulate mutations, insertions, and deletions due to selective pressure. The exact contribution of the microdiversity to microbial adaptive strategies is not clearly elucidated. However, high extent of intraspecific polymorphism is usually shown by bacterial species that are well adapted and thriving in extreme environments [20, 26, 59].

3.4. Hydrolytic Activities of Isolates. Beside the bacterial diversity of the southern Tunisia ecosystem, the current study assesses the biotechnological potential of desert isolates. The occurrence of hydrolytic enzymes could be used as biochemical marker to judge the microbial heterogeneity among the selected haloalkaliphilic bacteria. The ability of producing four different hydrolytic enzymes was tested qualitatively for 44 identified strains in the optimum growth conditions $(10 \%$ $\mathrm{NaCl}$ and $\mathrm{pH} 10$ ). A total of $15,17,16$, and 15 isolates were able to produce protease, lipase, DNase, and amylase, respectively
(Table 2). It is interesting to note that combined hydrolytic activities were also detected in many strains. One strain, BMG D102, affiliated to Halomonas elongata showed all four enzyme activities (PGPR strain as Mapelli et al). Strains affiliated to Bacillus saliphilus, Nesterenkonia halobia, Halobacillus litoralis, Piscibacillus salipiscarius, and Halobacillus profundi were able to produce 3 hydrolytic activities. Sanchez-Porro and colleagues [73] showed the abundance of these hydrolytic enzymes produced by moderately halophilic bacteria. It is worth noting that Gram-positive bacteria showed more hydrolytic activities. Similar variations in the production of these enzymes were reported among the bacteria isolated from Howz Soltan lake in Iran and Pulicat Lake in India $[15,23]$.

Two hydrolytic activities were demonstrated by 13 isolates affiliated to Halomonas, Halobacillus, Piscibacillus, Oceanobacillus, and Bacillus genera. However, unique hydrolytic activity was detected in 12 strains assigned to Halomonas, Salinicoccus, Piscibacillus, Virgibacillus, Oceanobacillus, and Marinococcus genera. On the other hand, 11 isolates, members of Nesterenkonia, Halomonas, Salinicoccus, and Arthrobacter genera, did not show any activity. This absence may be due to the released hydrolase quantity, not sufficiently enough to cause visible clearing zone on the plates.

The majority of the enzyme producers were affiliated to the Bacillus and Halomonas genera. Lipase was produced by $38.6 \%$ of the isolates; DNase was shown by $36.3 \%$ of the strains. For protease and amylase, $34 \%$ of the selected strains were able to release these enzymes. Similar results were observed for species isolated from saline alkaline systems affiliated to Halobacillus sp. [74], Nesterenkonia sp. [75], Virgibacillus sp. [76], and Bacillus sp. [77]. The most active strains are able to produce at least 3 hydrolases, were isolated from Chott el Djerid, Ksar Ghilane, and Sabkhet El Melah, and were all extremely haloalkalitolerant bacteria.

\section{Conclusion}

Our overall results indicate that haloalkaliphilic bacteria constitute an important part of the microbiota that inhabits arid and saline systems in southern Tunisia. A huge phenotypic and phylogenetic diversity was observed. Extremely haloalkalitolerant bacteria were the most dominant group and were affiliated to Bacillus, Nesterenkonia, Salinicoccus, and Marinococcus genera, of which several isolates could represent putative new species. A clear correlation between some species with specific ecological niches was also demonstrated. Besides, difference in the bacterial diversity rates between the studied sites was shown. The heterogeneity of haloalkaliphilic bacteria was confirmed by their hydrolytic enzymatic patterns variability including protease, lipase, DNase, and amylase. These enzymes are generally haloalkaliphilic which makes them interesting candidates to be employed in different industrial processes. The detected phenotypic and phylogenetic diversity points out that saline systems of southern Tunisia could represent a valuable source of new lineages and metabolites. 


\section{Acknowledgments}

The authors acknowledge the financial support from the European Union in the ambit of the Project BIODESERT (EU FP7-CSA-SA REGPOT-2008-2, Grant agreement no. 245746) and the Tunisian Ministry of Higher Education and Scientific research in the ambit of the laboratory Projects LR MBA206 and LR11ES31.

\section{References}

[1] L. J. Rothschild and R. L. Mancinelli, "Life in extreme environments," Nature, vol. 409, no. 6823, pp. 1092-1101, 2001.

[2] G. S. H. Soliman and H. G. Trueper, "Halobacterium pharaonis sp.nov., a new, extremely haloalkaliphilic archaebacterium with low magnesium requirement," Zentralblatt für Bakteriologie Mikrobiologie und Hygiene: I. Abt. Originale C, vol. 3, no. 2, pp. 318-329, 1982.

[3] K. Horikoshi, Alkaliphiles, Wiley Online Library, 2008.

[4] K. Horikoshi, "Alkaliphiles: some applications of their products for biotechnology," Microbiology and Molecular Biology Reviews, vol. 63, no. 4, pp. 735-750, 1999.

[5] H. Takami, Y. Takaki, and I. Uchiyama, "Genome sequence of Oceanobacillus iheyensis isolated from the Iheya Ridge and its unexpected adaptive capabilities to extreme environments," Nucleic Acids Research, vol. 30, no. 18, pp. 3927-3935, 2002.

[6] S. P. Singh, "Extreme environments and extremophiles," in National Science Digital Library (CSIR): E- Book, Environmental Microbiology, pp. 1-35, CSIR India, 2006.

[7] A. A. Joshi, P. P. Kanekar, A. S. Kelkar et al., "Cultivable bacterial diversity of alkaline Lonar lake, India," Microbial Ecology, vol. 55, no. 2, pp. 163-172, 2008.

[8] M. Foti, D. Y. Sorokin, B. Lomans et al., "Diversity, activity, and abundance of sulfate-reducing bacteria in saline and hypersaline soda lakes," Applied and Environmental Microbiology, vol. 73, no. 7, pp. 2093-2100, 2007.

[9] J. L. Kirk, L. A. Beaudette, M. Hart et al., "Methods of studying soil microbial diversity," Journal of Microbiological Methods, vol. 58, no. 2, pp. 169-188, 2004.

[10] K. Ohta, A. Kiyomiya, N. Koyama, and Y. Nosoh, "The basis of the alkalophilic property of a species of Bacillus," Journal of General Microbiology, vol. 86, no. 2, pp. 259-266, 1975.

[11] O. Shida, H. Takagi, K. Kadowaki, and K. Komagata, "Proposal for two new genera, Brevibacillus gen. nov. and Aneurinibacillus gen. nov," International Journal of Systematic Bacteriology, vol. 46, no. 4, pp. 939-946, 1996.

[12] J. Lu, Y. Nogi, and H. Takami, “Oceanobacillus iheyensis gen. nov., sp. nov., a deep-sea extremely halotolerant and alkaliphilic species isolated from a depth of $1050 \mathrm{~m}$ on the Iheya Ridge," FEMS Microbiology Letters, vol. 205, no. 2, pp. 291-297, 2001.

[13] S. Spring, W. Ludwig, M. C. Marquez, A. Ventosa, and K.H. Schleifer, "Halobacillus gen. nov., with descriptions of Halobacillus litoralis sp. nov. and Halobacillus trueperi sp. nov., and transfer of Sporosarcina halophila to Halobacillus halophilus comb. nov," International Journal of Systematic Bacteriology, vol. 46, no. 2, pp. 492-496, 1996.

[14] H. Schlesner, P. A. Lawson, M. D. Collins et al., “Filobacillus milensis gen. nov., sp. nov., a new halophilic spore-forming bacterium with Orn-D-Glu-type peptidoglycan," International Journal of Systematic and Evolutionary Microbiology, vol. 51, no. 2, pp. 425-431, 2001.
[15] H. Sahay, S. Singh, R. Kaushik, A. K. Saxena, and D. K. Arora, "Characterization of halophilic bacteria from environmental samples from the brackish water of Pulicat Lake, India," Biologia, vol. 66, no. 5, pp. 741-747, 2011.

[16] H. Sahay, S. Mahfooz, A. K. Singh et al., "Exploration and characterization of agriculturally and industrially important haloalkaliphilic bacteria from environmental samples of hypersaline Sambhar Lake, India," World Journal of Microbiology and Biotechnology, vol. 28, no. 11, pp. 3207-3217, 2012.

[17] Y. Ma, W. Zhang, Y. Xue, P. Zhou, A. Ventosa, and W. D. Grant, "Bacterial diversity of the Inner Mongolian Baer Soda Lake as revealed by $16 \mathrm{~S}$ rRNA gene sequence analyses," Extremophiles, vol. 8, no. 1, pp. 45-51, 2004.

[18] H. Baati, S. Guermazi, R. Amdouni, N. Gharsallah, A. Sghir, and E. Ammar, "Prokaryotic diversity of a Tunisian multipond solar saltern," Extremophiles, vol. 12, no. 4, pp. 505-518, 2008.

[19] R. Mwirichia, A. W. Muigai, B. Tindall, H. I. Boga, and E. Stackebrandt, "Isolation and characterisation of bacteria from the haloalkaline Lake Elmenteita, Kenya," Extremophiles, vol. 14, no. 4, pp. 339-348, 2010.

[20] B. Ettoumi, E. Bouhajja, S. Borin, D. Daffonchio, A. Boudabous, and A. Cherif, "Gammaproteobacteria occurrence and microdiversity in Tyrrhenian Sea sediments as revealed by cultivation-dependent and -independent approaches," Systematic and Applied Microbiology, vol. 33, no. 4, pp. 222-231, 2010.

[21] F. Mapelli, R. Marasco, E. Rolli et al., "Potential for plant growth promotion of Rhizobacteria associated with Salicornia growing in Tunisian hypersaline soils," BioMed Research International, vol. 2013, Article ID 248078, 13 pages, 2013.

[22] R. Margesin and F. Schinner, "Potential of halotolerant and halophilic microorganisms for biotechnology," Extremophiles, vol. 5, no. 2, pp. 73-83, 2001.

[23] R. Rohban, M. A. Amoozegar, and A. Ventosa, "Screening and isolation of halophilic bacteria producing extracellular hydrolyses from Howz Soltan Lake, Iran," Journal of Industrial Microbiology and Biotechnology, vol. 36, no. 3, pp. 333-340, 2009.

[24] N. Stivaletta, R. Barbieri, C. Picard, and M. Bosco, "Astrobiological significance of the sabkha life and environments of southern Tunisia," Planetary and Space Science, vol. 57, no. 5-6, pp. 597605, 2009.

[25] P. A. Dimitriu, S. K. Shukla, J. Conradt et al., "Nitrincola lacisaponensis gen. nov., sp. nov., a novel alkaliphilic bacterium isolated from an alkaline, saline lake," International Journal of Systematic and Evolutionary Microbiology, vol. 55, no. 6, Article ID 63647, pp. 2273-2278, 2005.

[26] A. Cherif, S. Borin, A. Rizzi, H. Ouzari, A. Boudabous, and D. Daffonchiol, "Bacillus anthracis diverges from related clades of the Bacillus cereus group in 16S-23S ribosomal DNA intergenic transcribed spacers containing tRNA genes," Applied and Environmental Microbiology, vol. 69, no. 1, pp. 33-40, 2003.

[27] E. W. Alm, D. B. Oerther, N. Larsen, D. A. Stahl, and L. Raskin, "The oligonucleotide probe database," Applied and Environmental Microbiology, vol. 62, no. 10, pp. 3557-3559, 1996.

[28] S. F. Altschul, W. Gish, W. Miller, E. W. Myers, and D. J. Lipman, "Basic local alignment search tool," Journal of Molecular Biology, vol. 215, no. 3, pp. 403-410, 1990.

[29] J. D. Thompson, D. G. Higgins, and T. J. Gibson, "CLUSTAL $\mathrm{W}$ : improving the sensitivity of progressive multiple sequence alignment through sequence weighting, position-specific gap penalties and weight matrix choice," Nucleic Acids Research, vol. 22, no. 22, pp. 4673-4680, 1994. 
[30] T. H. Jukes and C. R. Cantor, "Evolution of protein molecules," in Mammalian Protein Metabolism, H. N. Munro, Ed., pp. 21123, Academic Press, New York, NY, USA, 1969.

[31] S. Kumar, K. Tamura, and M. Nei, "MEGA3: integrated software for molecular evolutionary genetics analysis and sequence alignment," Briefings in Bioinformatics, vol. 5, no. 2, pp. 150-163, 2004.

[32] R. G. E. Murray, R. N. Doetsch, and C. F. Robinow, "Determinative and cytological light microscopy," in Methods for General and Molecular Bacteriology, P. Gerhardt, R. G. E. Murray, W. A. Wood, and N. R. Krieg, Eds., pp. 21-41, American Society for Microbiology, Washington, DC, USA, 1994.

[33] K. Horikoshi, "Production of alkaline enzyme by alkalophilic microorganisms. Part I alkaline protease produced by Bacillus," Agricultural Biological Chemistry, vol. 35, no. 221, pp. 1407-1414, 1971.

[34] M. A. Amoozegar, F. Malekzadeh, and K. A. Malik, "Production of amylase by newly isolated moderate halophile, Halobacillus sp. strain MA-2," Journal of Microbiological Methods, vol. 52, no. 3, pp. 353-359, 2003.

[35] K. Horikoshi, "Production of alkaline enzyme by alkalophilic microorganisms. Part III alkaline amylase produced by Bacillus no. A-40-2," Agricultural Biological Chemistry, vol. 35, pp. 17831791, 1971.

[36] H. Onishi, T. Mori, and S. Takeuchi, "Halophilic nuclease of a moderately halophilic Bacillus sp.: production, purification, and characterization," Applied and Environmental Microbiology, vol. 45, no. 1, pp. 24-30, 1983.

[37] C. Gutiérrez and C. González, "Method for simultaneous detection of proteinase and esterase activities in extremely halophilic bacteria," Applied Microbiology, vol. 24, no. 3, pp. 516517, 1972.

[38] I. Romano, L. Lama, B. Nicolaus, A. Gambacorta, and A. Giordano, "Bacillus saliphilus sp. nov., isolated from a mineral pool in Campania, Italy," International Journal of Systematic and Evolutionary Microbiology, vol. 55, no. 1, pp. 159-163, 2005.

[39] V. Torsvik and L. Overas, "Microbial diversity, life strategies, and adaptation to life in extreme soils," in Microbiology of Extreme Soils, Soil Biology, P. Dion and C. S. Nautiyal, Eds., vol. 13, Springer, Berlin, Germany, 2008.

[40] H. H. Zahran, "Diversity, adaptation and activity of the bacterial flora in saline environments," Biology and Fertility of Soils, vol. 25, no. 3, pp. 211-223, 1997.

[41] M. S. Dodia, Stability and folding of extracellular enzymes from haloalkaliphilic bacteria [Ph.D. thesis], Saurashtra University, Rajkot, India, 2005.

[42] M. S. Dodia, H. G. Bhimani, C. M. Rawal, R. H. Joshi, and S. P. Singh, "Salt dependent resistance against chemical denaturation of alkaline protease from a newly isolated haloalkaliphilic Bacillus sp," Bioresource Technology, vol. 99, no. 14, pp. 62236227, 2008.

[43] M. S. Dodia, C. M. Rawal, H. G. Bhimani, R. H. Joshi, S. K. Khare, and S. P. Singh, "Purification and stability characteristics of an alkaline serine protease from a newly isolated Haloalkaliphilic bacterium sp. AH-6," Journal of Industrial Microbiology and Biotechnology, vol. 35, no. 2, pp. 121-131, 2008.

[44] A. Hedi, N. Sadfi, M.-L. Fardeau et al., "Studies on the biodiversity of halophilic microorganisms isolated from El-Djerid salt lake (Tunisia) under aerobic conditions," International Journal of Microbiology, vol. 2009, Article ID 731786, 17 pages, 2009.

[45] R. B. Hoover, E. V. Pikuta, A. K. Bej et al., "Spirochaeta americana sp. nov., a new haloalkaliphilic, obligately anaerobic spirochaete isolated from soda Mono Lake in California," International Journal of Systematic and Evolutionary Microbiology, vol. 53, no. 3, pp. 815-821, 2003.

[46] B. Nowlan, M. S. Dodia, S. P. Singh, and B. K. C. Patel, "Bacillus okhensis sp. nov., a halotolerant and alkalitolerant bacterium from an Indian saltpan," International Journal of Systematic and Evolutionary Microbiology, vol. 56, no. 5, Article ID 63861, pp. 1073-1077, 2006.

[47] A. Ventosa, M. C. Márquez, M. J. Garabito, and D. R. Arahal, "Moderately halophilic gram-positive bacterial diversity in hypersaline environments," Extremophiles, vol. 2, no. 3, pp. 297304, 1998.

[48] Y. V. Boltyanskaya, E. N. Detkova, A. N. Shumskii, L. E. Dulov, and M. A. Pusheva, "Osmoadaptation in representatives of haloalkaliphilic bacteria from soda lakes," Mikrobiologiya, vol. 74, no. 6, pp. 738-744, 2005, English Translation in Microbiology, vol. 74, no. 6, pp. 640-645, 2005.

[49] V. Gürtler and V. A. Stanisich, "New approaches to typing and identification of bacteria using the 16S-23S rDNA spacer region," Microbiology, vol. 142, no. 1, pp. 3-16, 1996.

[50] D. Daffonchio, S. Borin, A. Consolandi, D. Mora, P. L. Manachini, and C. Sorlini, "16S-23S rRNA internal transcribed spacers as molecular markers for the species of the $16 \mathrm{~S}$ rRNA group I of the genus Bacillus," FEMS Microbiology Letters, vol. 163, no. 2, pp. 229-236, 1998.

[51] H. Jiang, H. Dong, B. Yu et al., "Microbial response to salinity change in Lake Chaka, a hypersaline lake on Tibetan plateau," Environmental Microbiology, vol. 9, no. 10, pp. 2603-2621, 2007.

[52] H. Hacěne, F. Rafa, N. Chebhouni et al., "Biodiversity of prokaryotic microflora in El Golea Salt lake, Algerian Sahara," Journal of Arid Environments, vol. 58, no. 3, pp. 273-284, 2004.

[53] J. L. Siefert, M. Larios-Sanz, L. K. Nakamura et al., "Phylogeny of marine Bacillus isolates from the Gulf of Mexico," Current Microbiology, vol. 41, no. 2, pp. 84-88, 2000.

[54] A. M. Sass, B. A. McKew, H. Sass, J. Fichtel, K. N. Timmis, and T. J. McGenity, "Diversity of Bacillus-like organisms isolated from deep-sea hypersaline anoxic sediments," Saline Systems, vol. 4, article 8, 2008.

[55] K. Horikoshi and T. Akiba, Alkalophilic Microorganisms: A New Microbial World, Springer, Heidelberg, Germany, 1982.

[56] T. A. Krulwich and A. A. Guffanti, "Physiology of Acidophilic and Alkalophilic Bacteria," Advances in Microbial Physiology, vol. 24, pp. 173-214, 1983.

[57] H. Takami and K. Horikoshi, "Analysis of the genome of an alkaliphilic Bacillus strain from an industrial point of view," Extremophiles, vol. 4, no. 2, pp. 99-108, 2000.

[58] H. Baati, R. Amdouni, N. Gharsallah, A. Sghir, and E. Ammar, "Isolation and characterization of moderately halophilic bacteria from tunisian solar saltern," Current Microbiology, vol. 60, no. 3, pp. 157-161, 2010.

[59] A. Guesmi, B. Ettoumi, D. El Hidri et al., "Uneven distribution of Halobacillus trueperi species in arid natural saline systems of southern Tunisian Sahara," Microbial Ecology, 2013.

[60] B. A. Lomstein, A. T. Langerhuus, S. D’Hondt, B. B. Jørgensen, and A. J. Spivack, "Endospore abundance, microbial growth and necromass turnover in deep sub-seafloor sediment," Nature, vol. 484, no. 7392, pp. 101-104, 2012.

[61] A. C. F. Dias, F. D. Andreote, F. Dini-Andreote et al., "Diversity and biotechnological potential of culturable bacteria from Brazilian mangrove sediment," World Journal of Microbiology and Biotechnology, vol. 25, no. 7, pp. 1305-1311, 2009. 
62] M. D. Collins, P. A. Lawson, M. Labrenz, B. J. Tindall, N. Weiss, and P. Hirsch, "Nesterenkonia lacusekhoensis sp. nov., isolated from hypersaline Ekho Lake, East Antarctica, and emended description of the genus Nesterenkonia," International Journal of Systematic and Evolutionary Microbiology, vol. 52, no. 4, pp. 1145-1150, 2002.

[63] A. W. Duckworth, W. D. Grant, B. E. Jones, and R. Van Steenbergen, "Phylogenetic diversity of soda lake alkaliphiles," FEMS Microbiology Ecology, vol. 19, no. 3, pp. 181-191, 1996.

[64] P. Gupta, G. S. N. Reddy, D. Delille, and S. Shivaji, “Arthrobacter gangotriensis sp. nov. and Arthrobacter kerguelensis sp. nov. from Antarctica," International Journal of Systematic and Evolutionary Microbiology, vol. 54, no. 6, pp. 2375-2378, 2004.

[65] R. R. De La Haba, D. R. Arahal, M. C. Márquez, and A. Ventosa, "Phylogenetic relationships within the family Halomonadaceae based on comparative $23 \mathrm{~S}$ and $16 \mathrm{~S}$ rRNA gene sequence analysis," International Journal of Systematic and Evolutionary Microbiology, vol. 60, no. 4, pp. 737-748, 2010.

[66] D. R. Arahal and A. Ventosa, "The family Halomonadaceae," in The Prokaryotes: An Evolving Electronic Resource for the Microbial Community, M. Dworkin, S. Falkow, E. Rosenberg, K. H. Schleifer, and E. Stackebrandt, Eds., Spring, New York, NY, USA, 2005.

[67] K. Pedersen, E. Nilsson, J. Arlinger, L. Hallbeck, and A. O'Neill, "Distribution, diversity and activity of microorganisms in the hyper-alkaline spring waters of Maqarin in Jordan," Extremophiles, vol. 8, no. 2, pp. 151-164, 2004.

[68] P. V. Morais, R. Francisco, R. Branco, A. P. Chung, and M. S. Da Costa, "Leucobacter chromiireducens sp. nov, and Leucobacter aridicollis $s p$. nov., two new species isolated from a chromium contaminated environment," Systematic and Applied Microbiology, vol. 27, no. 6, pp. 646-652, 2004.

[69] S. Labana, G. Pandey, and R. K. Jain, "Desulphurization of dibenzothiophene and diesel oils by bacteria," Letters in Applied Microbiology, vol. 40, no. 3, pp. 159-163, 2005.

[70] G.-J. Chee and H. Takami, "Alternative splicing by participation of the group II intron ORF in extremely halotolerant and alkaliphilic Oceanobacillus iheyensis," Microbes and Environments, vol. 26, no. 1, pp. 54-60, 2011.

[71] N. Toor, K. S. Keating, S. D. Taylor, and A. M. Pyle, "Crystal structure of a self-spliced group II intron," Science, vol. 320, no. 5872, pp. 77-82, 2008.

[72] K. K. Kim, L. Jin, H. C. Yang, and S.-T. Lee, "Halomonas gomseomensis sp. nov., Halomonas janggokensis sp. nov., Halomonas salaria sp. nov. and Halomonas denitrificans sp. nov., moderately halophilic bacteria isolated from saline water," International Journal of Systematic and Evolutionary Microbiology, vol. 57, no. 4, pp. 675-681, 2007.

[73] C. Sánchez-Porro, E. Mellado, C. Bertoldo, G. Antranikian, and A. Ventosa, "Screening and characterization of the protease CP1 produced by the moderately halophilic bacterium Pseudoalteromonas sp. strain CP76," Extremophiles, vol. 7, no. 3, pp. 221228, 2003.

[74] H. R. Karbalaei-Heidari, M. A. Amoozegar, M. Hajighasemi, A.-A. Ziaee, and A. Ventosa, "Production, optimization and purification of a novel extracellular protease from the moderately halophilic bacterium Halobacillus karajensis," Journal of Industrial Microbiology and Biotechnology, vol. 36, no. 1, pp. 2127, 2009.

[75] S. Bakhtiar, R. J. Estiveira, and R. Hatti-Kaul, "Substrate specificity of alkaline protease from alkaliphilic feather-degrading
Nesterenkonia sp. AL20," Enzyme and Microbial Technology, vol. 37, no. 5, pp. 534-540, 2005.

[76] S. Sinsuwan, S. Rodtong, and J. Yongsawatdigul, "Characterization of $\mathrm{Ca}^{2+}$-activated cell-bound proteinase from Virgibacillus sp. SK37 isolated from fish sauce fermentation," LWT-Food Science and Technology, vol. 41, no. 10, pp. 2166-2174, 2008.

[77] M. Kamekura and H. Onishi, "Protease formation by a moderately halophilic Bacillus strain," Journal of Applied Microbiology, vol. 27, no. 4, pp. 809-810, 1974. 

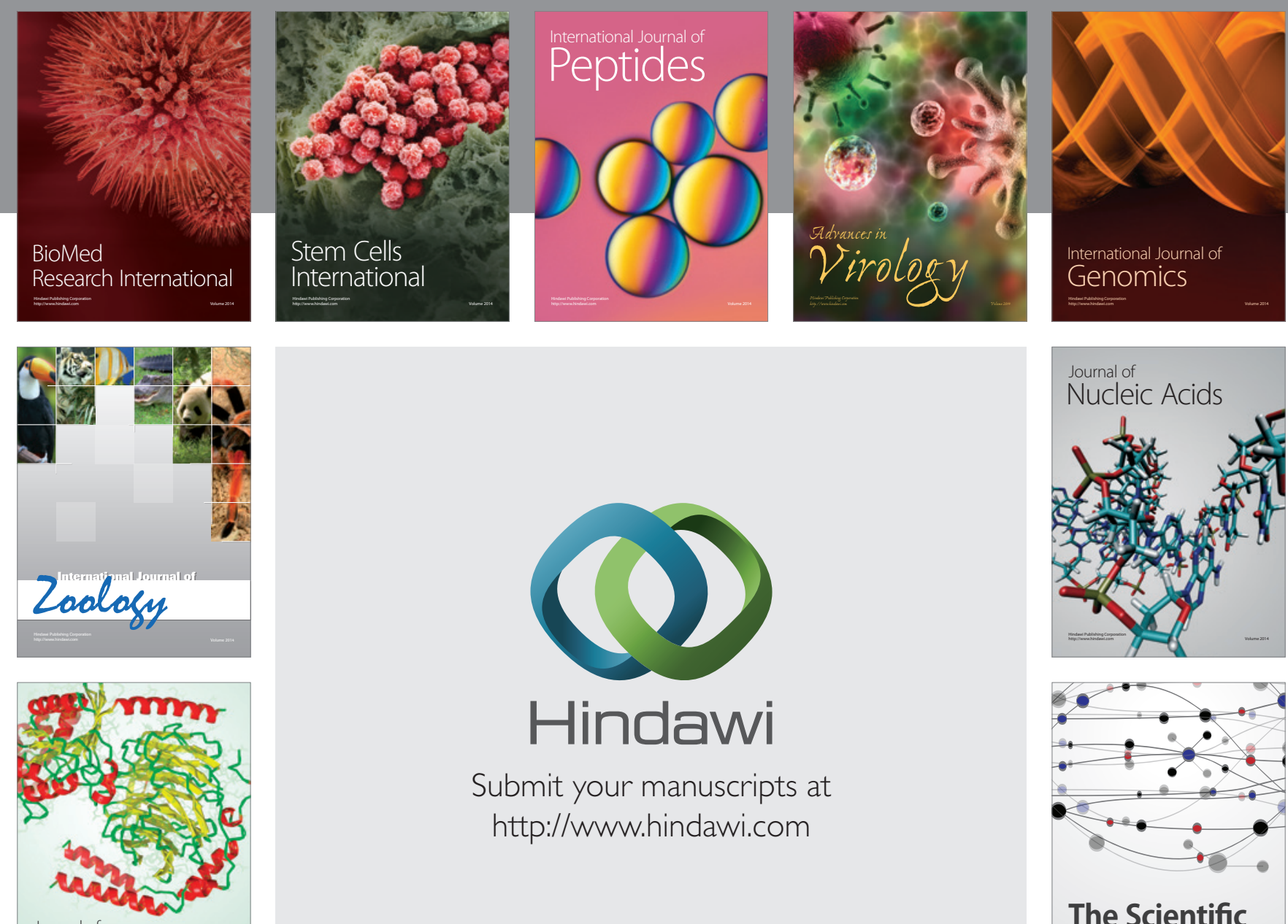

Submit your manuscripts at

http://www.hindawi.com

Journal of
Signal Transduction
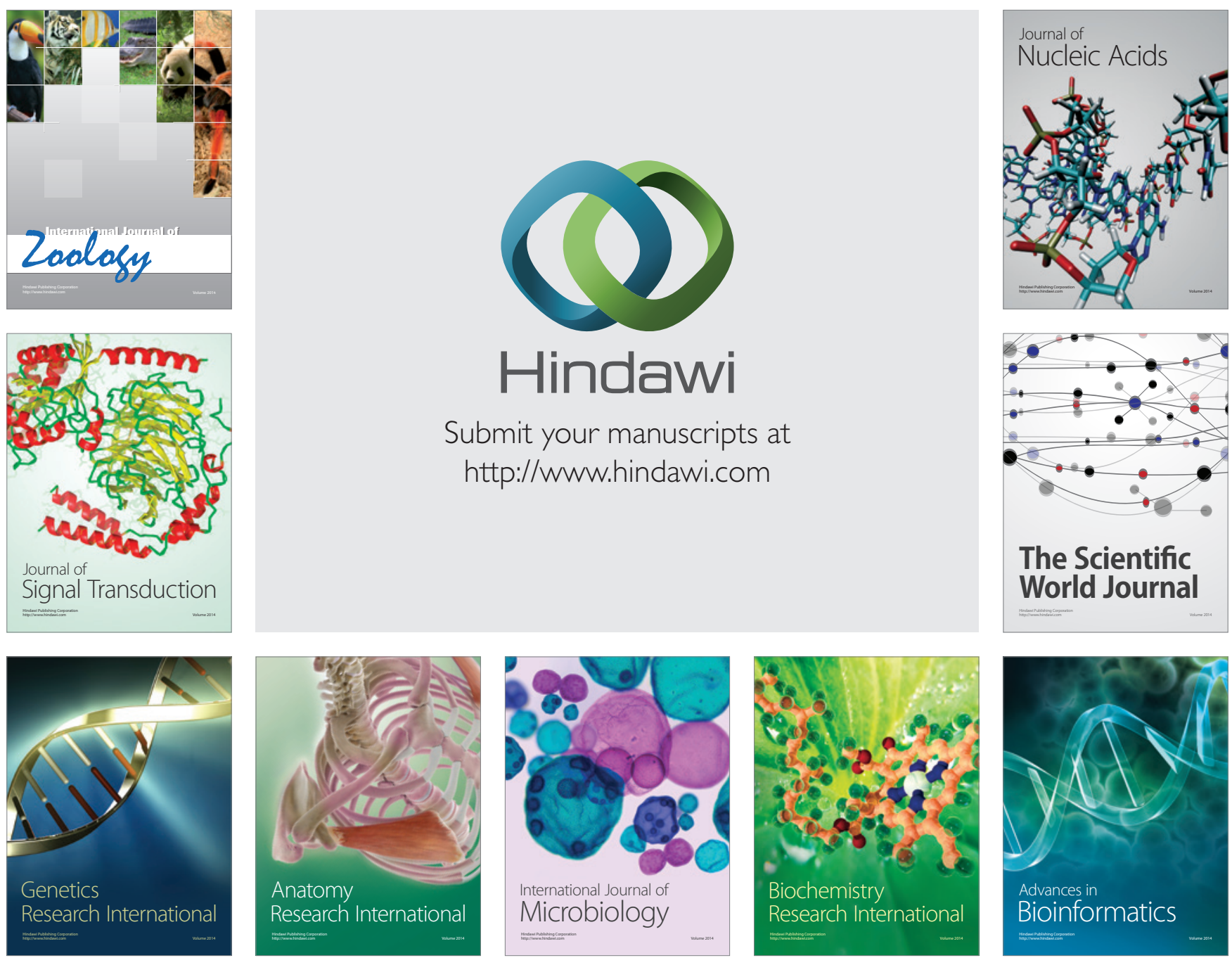

The Scientific World Journal
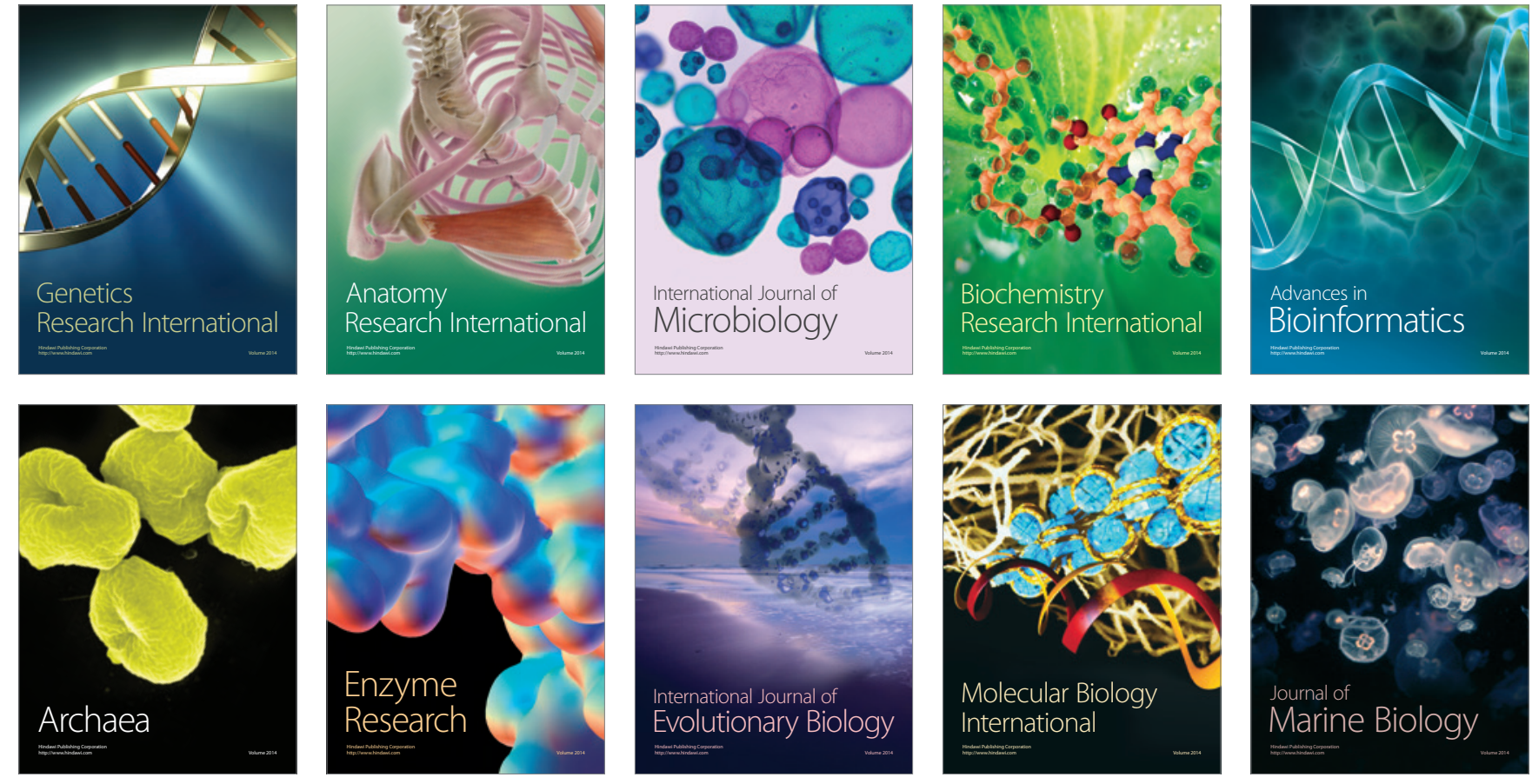